\title{
Mission Statement and Consolidation of the Efforts of Its Staff
}

\author{
Vladimir S. Lazarev
}

\begin{abstract}
Crafting the mission statements of organizations, enterprises, etc., is a regular part of the management policy in a number of Western countries (especially the USA, Canada and UK) nowadays. Many American and British readers know what an important role the mission statements play in the activity of libraries and information centers. In the Republic of Belarus, the very first mission statement appeared in a library, in 1996. Designing and creating a mission statement is explored. [Article copies available for a fee from The Haworth Document Delivery Service: 1-800-342-9678. E-mail address: < getinfo@haworthpressinc.com>Website: <http://www:HaworthPress.com> (C) 2001 by The Haworth Press, Inc. All rights reserved.]
\end{abstract}

KEYWORDS. Mission statements

\section{INTRODUCTION}

Crafting the so-called mission statements (or missions) of organizations, enterprises, etc., is a regular part of management policy in a

Vladimir S. Lazarev is Chief of Scientific Information Service Department, Research Division, Belarusian State Polytechnic Academy (technical university), and Vice-Chairman of the Committee for International Liaison of Belarusian Library Association.

Address correspondence to: Vladimir S. Lazarev, State Polytechnic Academy, 65-13 Fr. Skaryna Ave, Minsk, 220027, The Republic of Belarus (E-mail:<vlazarev@ bspa.unibel.by>).

The author is indebted to Vladimir A. Golubev, who offered him the idea of this article and supplied him with the references $[4 ; 7 ; 8,12]$ and many other examples.

Journal of Interlibrary Loan, Document Delivery \& Information Supply

Vol. 11(3) 2001

2001 by The Haworth Press, Inc. All rights reserved. 
number of Western countries (especially the USA, Canada and UK) nowadays. Mission statements are also attributed to the organizations and establishments of culture (such as universities, schools, libraries, research institutions, etc.) and even to the certain sole social actions (conferences, exhibitions, etc.). A lot of American and British readers know what an important role the mission statements play in the activity of libraries and information centers. In the Republic of Belarus, the home country of the author of this paper, the very first mission statement appeared in a library, but not until January of 1996.

Mission statement phenomenon is an absolute novelty for Belarusian librarians: in the whole country as well in the whole Soviet Union there was no tradition of the development and application of such a document. Therefore, those who tried to construct the mission statement without previous exploration of the phenomenon were not successful. Because of this, the author of the paper started to collect the mission statements the libraries and other institutions and organizations of the USA, Canada and the UK so to reveal some "secrets" of crafting an effective mission statement. The first results of such an analysis and the first, quite obviously for experienced managers, recommendations were published in the magazine of Belarusian librarians. $^{1}$

In 1998 the co-author of the first mission statement in Belarus, Vladimir Golubev, provided the author with some methodic literature on the problem and shared his own collection of the mission statements with him. The analysis of these materials resulted in some more recommendations for Belarusian librarians. ${ }^{2,3}$ At the same time, it became obvious that quite a lot of unsolved problems about the mission statements exist not only in the home country of the author, but also in the countries that have good traditions and practice in crafting and use of mission statements. Therefore, some parts of the author's review and some of his conclusions and recommendations, might be of interest not only for Belarusian librarians, but also for the colleagues from any country where mission statements are practiced.

Regarding this, the paper deals with the author's viewpoint on the definition of mission statement and on one of the specific mission statement's functions, viz., the one of consolidation of the efforts of the stuff. 


\section{TOWARDS THE MORE USEFUL MISSION STATEMENT DEFINITION}

One of the most common mission statement definitions is the following: "The organization's mission is a broadly defined but enduring statement of purpose that distinguishes it from other organizations of its type and identifies the scope of its operations in product and market terms. Not only does the organization's mission embody the strategic decision makers' philosophy, it also reveals the image of the organization that they seek to project, reflects the organization's self-concept, and indicates the principal product or service areas and the primary customer or clients' needs that the organization will attempt to satisfy" [pp. ix-x]. ${ }^{4}$

It is known that an efficient mission statement contributes to the formation of the unique organization's image. This is achieved both by the distinctly true description of an organization's activity in the mission statement and by the use of the specific style that is associated with a concrete organization. A good mission statement also helps the employees (as well as the top management of the organization) to realize why does the organization exist, what needs it does fulfil, etc. $\left[\right.$ p. x]. ${ }^{4}$

Metaphorically speaking, a mission statement is a documentary reflector of the organization that is looked at both by the employees and visitors. Functionally, it is also an aid of consolidation of the efforts of the staff; a text that makes the staff be proud of the organization and that stimulates the labor of the staff. This is a very important function of a mission, though it is not reflected in the above definition. However, it is reflected in some other pieces of methodic literature, and it becomes obvious while reading some of the good mission statements.

In order to craft an efficient mission statement of a library one needs to consult some special handbooks and examples of the relevant existing mission statements; also, one has to have an understanding of what is going to be said. However, and our experience demonstrated it too vividly, it is not enough when the mission statement is being developed at first, especially if a potential author has never tried to develop such a document before. In this case, one also needs such a brief mission statement definition that contains the full well-organized list of the specific functions, characteristics and elements of an ideal mission statement. Such a definition may be used by an author of a draft 
of a mission statement as a kind of a check list, as a helpful prompter. It is so easy to miss some sufficient mission statement element in a first draft-especially if not all the elements are known!

From this viewpoint, the existing brief definitions of the mission statement (e.g., "The mission describes the organization's product, service, market and technology in a way that reflects the values and priorities of the strategic decision makers" [p. x], "The document that contains the description of the actual or desired characteristics and aims of the organization" [p. 31], etc.), ${ }^{5}$ are not good, as they do not contain such full lists. The more extended known definitions are also not good for this purpose, as they are not sufficiently organized.

The above statements were exactly the reason for the author to start with developing such a definition that could serve as a prompter in the further activity of writing the mission statement itself.

The following list of the compulsory functions, elements and characteristics of an ideal mission statement was determined by the author because of the analysis of the methodic literature and of the various examples of mission statements.

\section{MISSION STATEMENT}

1. Distinguishes the organization from other organizations of its type.

2. Indicates the principal product or service areas.

3. Describes geographic parameters of organization (e.g., Marseilles, France, European Union, Europe, etc.).

4. Embodies the strategic decision making philosophy (in particular:

(4.1.) by featuring the statement of purpose;

(4.2.) by describing the strategic objectives, intent and business direction for the organization;

(4.3.) by describing the organization's work in the context of them)

5. Reveals the image of the organization that its managers seek to project, reflects the expectations of the public. 
6. Reflects the organization's self-concept.

7. Embodies the primary client needs that the organization will attempt to satisfy.

8. Demonstrates that the organization's top priority is the client and reflects the concern for quality of the organization's activity

9. Stimulates the effective and creative work of the staff, consolidates the efforts of the staff members (in particular:

(9.1.) By indicating the organization's ability to satisfy the principal desires of employees and stockholders over the long term;

(9.2.) by featuring a most important role of the staff;

(9.3.) by the use of such wording and/or style that make the staff and proud of the organization that inspires the wish to work more effectively for the sake of its strategic aims)

10. Reflects the other values, priorities and fundamental beliefs of the organization

11. Describes the technology that is used in the organization's work.

The above functional definition seems to be good not only for a novice at crafting a mission, but, as it can be judged from a lot of mission statement examples, should be used elsewhere. It was reported at Belarusian Library Association meeting ${ }^{3}$ and it was used by the author and his team for designing the drafts of the mission statements of various bodies of the Belarusian State Polytechnic Academy.

\section{MISSION STATEMENT AS AN AID OF CONSOLIDATION OF THE STAFF}

Among the various important functions of the mission statement, function 9, the one of stimulation the effective and creative work of the staff, consolidation the efforts of the stuff members-draws our special attention. First, because there was a tradition of "moral stimulation" of the labor that existed in the countries of the former Soviet Union for a long time, but then was practically lost-while there is still 
a need of aid of this kind. Second, because as we have only started crafting mission statements, it was noticed immediately that the teamwork on a draft mission statement consolidated the involved staff as nothing else did before, so the corresponding effectiveness of a mission was confirmed at once. Therefore, the search for effective examples of the wording that stimulate the effective and creative work of the staff and consolidate its efforts became the point of our further concern.

Among the collected examples (to be considered and, possibly, followed) the following ones seem to be worth being quoted and discussed here:

In every library in the nation, quality library service to the young adults is provided by a staff that understands and respects the unique informational, educational and recreational needs of teenagers. ..." (italicized by the author-V.L.) [6, p. 121-22]

To our mind, the above example is the combination of all the three approaches (9.1.-9.3.).

Our product is steel.

Our strength is people. [7, p. 188]

This example (extracted from the mission statement of DOFASCO Inc.-a steel industry enterprise) seems to be a combination of the (9.2.) and (9.3.) approaches.

"We are committed to and dependent upon our people. THE DIME will:

- respect the dignity and worth of each individual,

- offer staff the training and development necessary for them to excel at their job,

- encourage each individual to advance as far as their talent and commitment will take them,

- provide fully competitive pay and benefits, tied to results" [p. 187]. ${ }^{7}$

The quoted example seems to be more effective, in a way, than the previous one. Besides (9.2.) and (9.3.), the (9.1.) approach is used in a way in the quoted wordings (the corresponding fragment is italicized by the author). 
The following is an example of a fragment of the mission statement that fulfills function (9) and function (10) simultaneously i.e., not only encourages employees to work effectively, but also reflects at the same time some of the principle organization's values. This example is another fragment from the same mission statement of THE DIME savings bank.

"Our dominant style and approach will be teamwork. We believe that:

- we are stronger working together,

- the foundation for teamwork is trust and management must earn that trust,

- there is no place in THE DIME for those who think first of themselves ....,

- teamwork is necessary to compete effectively." $[\mathrm{p} .186]^{7}$

Some wording from the first library mission statement in Belarus-the one of the Belarusian Agricultural Library- worth being quoted in the context of the subject matter of the present paper.

- "We strive to provide excellent information service and are particular about the achievement of the international standards of information service."

- "We believe in professional and moral value of each Library employee and welcome his or her individuality,

- "We welcome open communication and cooperation with individuals and professional groups within the Library and in the information commonwealth, and consider ourselves as one team",

- "Professional ethics of the Library employees demands them to do their utmost to meet information requirements of the users." 8 The familiar combination of (9.2.) and (9.3.) is used in the quoted wordings.

The example of the implementation of function (9) in the mission statement of the British Library is quite noticeable. In particular, it is proclaimed that the British Library has "expert staff" that gives "ready access to our collections in our reading rooms and by remote supply," is "committed to maintaining our position of leadership by embracing innovative, cost-effective and flexible methods of working." If anyone thinks that nothing is said there to encourage the 
efforts of the staff, let him (her) pay attention to the choice of the words italicized by the author. E.g. "expert staff" instead of "staff" or "employees," "committed to maintaining our position of leadership by embracing ... methods ..." instead of "uses . . . methods. . . ." The wordings are strongly emotional; they seem to inspire the workers to work really effectively.

A simple example of the use of approach (9.2.) in a mission statement may be taken from the mission of the Lincoln Trail Library System: "The individual contribution of well-trained staff of LTLS and member libraries is essential to quality service."10

The very short mission statement of The Library Association of the United Kingdom indicates the Association's ability to satisfy some of the principal needs of its members (9.1.), viz. "The Library Association is . . . committed to enabling its members to achieve and maintain the highest professional standards." 11 (Though this Association makes a lot of sufficient efforts for the social protection of its members, it is not-unfortunately-mentioned in the mission statement.)

The next group of examples is taken for this article from the mission statement of The National Agricultural Library. Throughout the mission statement a lot is said about the role and qualification of library staff, and a lot of wordings are really inspiring.

- "We strive to provide excellent service,"

- "We believe we have special responsibility to provide leadership to the library and information communities ..."

- "We are committed to the highest standards of ethics and integrity ....,"

- "We believe that each employee is valuable and NAL is strengthened by the diversity of the staff ...,"

- "We believe that staff development is critical to accomplish our mission." 12

The last two items seem to be a marvelous find! But as for "highest standards of ethics and integrity," the wording of this kind is rather fuzzy, while the ill-defined terms are strongly not recommended to be used in the mission statements [p. 6]..$^{7}$

And finally, some examples from a mission statement of a university. One of the specific features of such missions is the necessity to mention the importance not only of the staff, but of the students, too; 
and to indicate the ability of a university to satisfy the principal desires of the latter. This function (modified 9.1. that should be taken into account for the mission statements of university and colleague library in a way) is more or less sufficiently presented in the mission statement of the Loughborough University:

"We are ... committed to:

- an environment in which academic freedom, scholarship and initiative can flourish, and the professional development of all staff is encouraged ...;

- comprehensive care and support of students in partnership with Loughborough Students' Union;

- accommodation of a very substantial portion of students in residences on a large and attractive campus ...;

- provision of cultural and artistic facilities to enrich the experience of staff and students."13

The author hopes that the above examples will be useful to the authors of the future mission statements of the establishments of libraries and information centers. As a lot of the mission statements from the author's collection do not fulfil function (9), the present consideration of this function and the presented collection of the wordings seem to be still of more importance.

\section{ENDNOTES AND REFERENCES}

1. Lazarev V.S. How to write a mission statement of a library; Bibliyatechny svyet [Library World], 1999, N 2, p. 25-27 (in Russian).

2. Lazarev V.S. Mission statements of libraries and associations: definition, essence, necessity, efficiency. Towards formulation of the problem [in Belarus]; in: Modern library: the concept of development: Abstracts of the Presentations at the International Scientific-and-Practical Conference (11-14 May, 1999). Minsk, KrasikoPrint Publishers Ltd., 1999, p. 39-41 (in Russian).

3. Lazarev V.S. Library mission statement as an aid of consolidation of the staff; in: Information resources of libraries and their staff maintenance: Materials of the International Scientific-and-Practical Conference (23-26 May, 2000). Minsk, Krasiko-Print Publishers Ltd., 2000, p. 16-20 (in Russian).

4. Pearce II J.A. Foreword in: Graham J.M., Havlick W.C. Mission statement: A guide to the corporate and non-profit sectors, New York, London: Garland Publishing Inc., 1994.

5. Librarian's Dictionary in Management and Marketing, Moscow: State Public Scientific and Technical Library, 1995 (in Russian). 
6. Young Adult Library Service Association; in: ALA Handbook of Organizations, 1998-99: An annual guide to member participation: A supplement to the American Libraries, S.1.: American Library Association, s.a., p. 121-124. (This handbook was sent to the author by Michael Dowling.)

7. Graham J.M., Havlick W.C. Mission statement: A guide to the corporate and non-profit sectors, New York, London: Garland Publishing Inc., 1994.

8. www.belal.minsk.by/about/mission/index.htm

9. The mission statement was e-mailed to the author by Hazel Dakers.

10. Lincoln Trail Library System.-S.1.., s.a.-(a booklet).

11. Mission Statement.-S.1.: The Library Association, s.a.-(a booklet).

12. The National Agricultural Library / US Department of Agriculture.-S. 1., 1994 (a booklet).

13. http://www:lboro.ac.uk/service/std/joboflect/mission.html (sent by Paul Sturges). 